Pamiętnik Literacki 2013, 3, s. 185-194
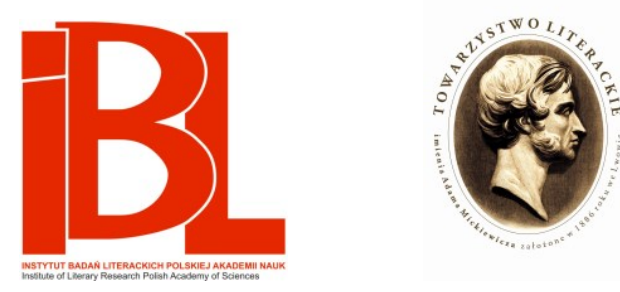

„Chcesz być groźnym, a uciekasz...”

Nad komentarzem do epinikionów

moskiewskich Jana Kochanowskiego

Roman Krzywy 


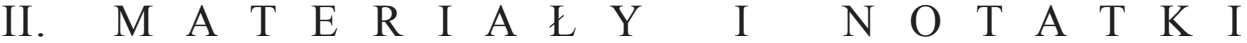 \\ Pamiętnik Literacki CIV, 2013, z. 3 PL ISSN 0031-0514}

ROMAN KRZYWY

(Uniwersytet Warszawski)

\section{„CHCESZ BYĆ GROŹNYM, A UCIEKASZ...” NAD KOMENTARZEM DO EPINIKIONÓW MOSKIEWSKICH JANA KOCHANOWSKIEGO}

Odę $O$ wzięciu Połocka ogłosił Kochanowski w zbiorku Pieśni trzy, wydanym na początku roku $1580 \mathrm{w}$ Warszawie. Broszura wyszła spod pras tzw. drukarni latającej, prowadzonej przez Walentego Łapczyńskiego, który w tym samym czasie opublikował łacińską pieśń Jana z Czarnolasu De expugnatione Polottei $(O$ zdobyciu Połocka), również opiewającą zwycięstwo Stefana Batorego ${ }^{1}$. Oba wiersze weszły później w skład zbiorów lirycznych: polski utwór włączył poeta bez większych zmian do Pieśni ksiag dwojga (II 13), łaciński zamyka tom Lyricorum libellus (12), dzięki czemu zostały wkomponowane w polifoniczny dyskurs na temat cnoty, mądrości i wielowymiarowości ludzkiej egzystencji, dyskurs budowany z ód poświęconych rozmaitym zagadnieniom, którego całościowa wymowa wciąż domaga się, jak sądzę, baczniejszej uwagi w kontekście antropologii humanistycznej. Pierwotnie jednak cel obu epinikionów wyczerpywały zadania propagandowo-pochwalne, co pozwala łączyć te utwory z okolicznościowym nurtem literatury².

W odzie wernakularnej zastanawia wiadomość o rejteradzie Iwana Groźnego, który przed oblężeniem Połocka słał do króla Rzeczypospolitej pełne dumnych pogróżek listy, a po wkroczeniu armii Batorego w granice państwa moskiewskiego miał z przerażenia - jak twierdzi Kochanowski - zbiec gdzieś daleko na północ. W pieśni II 13 przeczytać można:

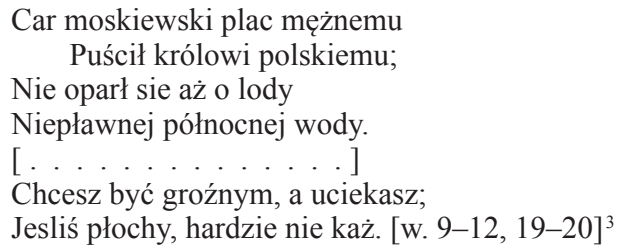

1 Zob. P. B u c h w a ld - P e 1 c o w a, Dawne wydania dziet Jana Kochanowskiego. Warszawa 1993, s. 90-91.

2 Zob. J. N ow a k-Dłużew ski, Okolicznościowa poezja polityczna w Polsce. Pierwsi królowie elekcyjni. Warszawa 1969, s. 171-173.

3 J. Ko ch a now ski, Pieśni. Wyd. Sejmowe. Oprac. M. R. Ma ye now a i K. Wilc zewska, przy udziale B. Otwinowskiej, oraz M. Cytowska. Wrocław 1991, s. 194. BPP, B 26. We wszystkich przytoczeniach pomijam rozróżnienie $a$ jasnego i pochylonego. 
Podobną informację podał twórca w odzie łacińskiej, ilustrując ucieczkę Iwana rozbudowanym porównaniem do wilka, który porzuca zdobycz ze strachu na widok lwa, będącego w wierszu figurą męstwa polskiego monarchy:

Sam o swą własną jeno dbając skórę,

Ostrogą konia pędzącego bodzie,

Aż się zatrzyma kędyś w Boreasza

Mroźnego grodzie.

Tak wilk, co szarpiąc czeka na bezdrożu,

Chociaż nie syty, jeszcze gdy z daleka

Ujrzy lwa, ogon pod brzuch podwinąwszy

$\mathrm{Z}$ miejsca ucieka.

Łupy porzuca, lubo mimo chęci,

Jeszcze ociąga się, lecz z drugiej strony

Niebezpieczeństwo czując bliskie, czmycha

W las, przerażony. [w. 29-40] ${ }^{4}$

Autorki komentarza w Wydaniu Sejmowym opatrzyły wzmiankę na temat rejterady cara uwagą:

Wiadomo, że Iwan IV czekał na rozstrzygnięcie bitwy o Połock w Pskowie, wiersze te więc nie mają w sensie dosłownym uzasadnienia historycznego, może jednak chodzi o hiperboliczne określenie oddalenia się na północ 5 .

Zofia Głombiowska natomiast informację podaną w pieśni De expugnatione Polottei próbuje thumaczyć w odmienny sposób:

poecie chodzi zapewne o to, że car nie zdecydował się na bezpośrednie starcie z armią polskiego króla, nie doszło zresztą w ogóle do żadnej bitwy w otwartym polu, wojska moskiewskie kryły się za wałami i palisadami zamków ${ }^{6}$.

Jednak w obu utworach wyraźnie mowa o pośpiesznym opuszczeniu wojennego teatrum, by ratować życie, a w pieśni polskiej miejsce ucieczki zostało nawet dokładniej określone: władca moskiewski dotrzeć miał aż do skutego lodem Oceanu Arktycznego, którego wody oblewające północną Azję na ówczesnych mapach nosiły nazwę Mare Glaciale ${ }^{7}$. Owszem, jest to hiperbola, ale wyłącznie tchórzostwa - odmierzanego przebytą odległością, której wielkość oddziaływać miała na wyobraźnię. Jeśli bowiem idzie o sam fakt carskiej dezercji, poeta zdaje się nie mieć żadnych wątpliwości. Tymczasem, jak to lakonicznie ujął XIX-wieczny historyk: „Iwan Groźny zajął główne stanowisko w Pskowie, skąd się, tchórz z natury, podczas całej wyprawy nie ruszył"8.

Rodzi się zatem pytanie, czy Kochanowski celowo manipulował faktami, by skontrastować w celach panegirycznych cnotę militarną Stefana Batorego ze stra-

4 J. K o c h a n o w s ki, Oda XII. O zdobyciu Połocka. W: Z łacińska śpiewa Stowian Muza. Elegie-foricenia - liryki. Przeł. L. S t a ff. Wstęp Z. Ku b i a k. Warszawa 1982, s. 210.

5 Objaśnienia. W: K o c h a n o w s k i, Pieśni, s. 444.

6 Z. G ł o m b i o w s k a, Łacińska oda Jana Kochanowskiego o zdobyciu Połocka. Tekst i komentarz. „Studia Classica et Neolatina”. T. 9 (2010): Na przestrzeni wieków..., s. 119.

7 Zob. np. mapę państwa moskiewskiego w: S. von Herbers te in, Moscoviter wunderbare Historien [...]. Basel 1567, s. nlb. 14-15.

8 J. S z u j s k i, Dzieje Polski podtug ostatnich badań. T. 3: Królowie wolno obrani, cz. 1: 1572-1668. Lwów 1864, s. 61. 
chem Iwana Groźnego, czy też utrwalił krążące wtedy pogłoski, które wynikały z braku pewnej wiedzy na temat miejsca przebywania cara podczas zmagań wojennych.

Pierwszą ewentualność zdaje się potwierdzać tradycja literacka. Jak zauważył niedawno Jakub Niedźwiedź, zastanawiając się, czy Kochanowski mógł inspirować się w swych wierszach ,moskiewskich” twórczością nowołacińską wczesnego renesansu, wers 85 Jezdy do Moskwy (,Moskiewski, komu grożąc, sam się teraz boi"') ${ }^{9}$ to niemal dosłowne tłumaczenie wersu 42 z Carmen de victoria Sigismundi (Pieśni o zwycięstwie Zygmunta I) Jana Dantyszka z 1514 roku, heksametrycznego epinikionu, sławiącego zwycięstwo pod Orszą wojsk Zygmunta Starego nad Wielkim Księstwem Moskiewskim ${ }^{10}$. Co więcej, autor łacińskiego poematu, aby wyolbrzymić klęskę Wasyla III, przekonuje go, że choćby zbiegł nad Nil, nad Cieśninę Gibraltarską lub nawet na mityczną Thule, nie może czuć się bezpiecznie. Myśl spuentował Dantyszek następująco:

Ten, kogo dawniej musiano się lękać, dziś sam się obawia:

Błądzi po gajach i lasach, nie mając już stałej siedziby. [w. 42-43] ${ }^{11}$

Takie ujęcie skutków pogromu, łączące ucieczkę cara z hiperbolizacją polsko-litewskiej potencji, mogło stanowić dla późniejszego twórcy istotny impuls. Oczywiście, dyskretne nawiązania w Jeździe do Moskwy do poematu z początku XVI wieku nie wykluczają reminiscencji w pieśniach sławiących glorię połocką. Kusi teza, że Jan z Czarnolasu postanowił ukazać Batorego jako godnego następcę wielkiego Jagiellona, władcę elekcyjnego legitymizowanego przez wiekopomne dokonania wojenne.

Nie mniej prawdopodobna jest jednak i druga ewentualność. Jakieś niepewne wieści na temat rzekomej rejterady Iwana Groźnego musiała odnotować opinia publiczna. Ćwierć wieku po wojnach batoriańskich Stanisław Niemojewski, dworzanin Zygmunta III Wazy, zesłany do Biełozierska (ok. $500 \mathrm{~km}$ na północ od Moskwy) po przewrocie pałacowym w Moskwie z 1606 roku, zanotował w swym pamiętniku:

przywlekli nas na to Białe Jezioro. Spodziewaliśmy się, że przecie miało co być według udawania i chwalenia nam tego zacnego grodu i miasta, więc i z sławy tej, że wielki kniaź Iwan Wasylewicz, kiedy mu król Stefan dokuczał, na tę fortecę uciekać chciał. Alić miasto sławne nędzą, miejsce puste między lasy i błoty ${ }^{12}$.

Uwaga dotyczy, co prawda, intencji cara i nie precyzuje, podczas której wy-

9 Tu i dalej numeracja wersów odsyła do: J. K o c h a n o w s k i, Dzieła polskie. T. 2. Oprac. J. Krzyż a n o w s ki. Wyd. 6. Warszawa 1969.

10 J. N i e d ź w i e d ź, Oda XII „De expugnatione Polottei” wśród szesnastowiecznych (kon)tekstów. W zb.: Twórczość Jana Kochanowskiego w kontekście nowołacińskiej literatury europejskiej i polskiej. Red. G. Urban-Godziek. Kraków 2010, s. 95-96 (publikacja internetowa: http://neolatina. bj.uj.edu.pl/main/reports.html).

${ }_{11}$ J. D a n ty s z e k, O zwycięstwie Zygmunta I, króla polskiego, nad Moskalami. Mała sylwa. W: Utwory poetyckie. Przeł. J. H a rh a la. Rzecz o życiu Dantyszka napisał R. G a n s z y n i e c. Lwów 1938, s. 22.

${ }_{12} \mathrm{~S}$. N i e m o j e w s k i, Diariusz drogi spisanej i różnych przypadków pociesznych i żałosnych prowadzą córkę Jerzego Mniszka, Marynę, Dymitrowi Iwanowiczowi w roku 1606. Wyd. R. K r z yw y. Warszawa 2006, s. 201. 
prawy Batorego nosił się Iwan z zamiarem ucieczki, mimo to przecież utrwala starą pogłoskę. W literaturze z epoki najczęściej wiązano ją jednak nie z oblężeniem Połocka, lecz z późniejszą o 3 lata wyprawą pod Psków, a mówiąc dokładniej z rajdem dywersyjnym Krzysztofa Radziwiłła „Pioruna”, któremu król polecił na początku sierpnia 1581 zapuścić się z kilkutysięcznym pułkiem w głąb państwa moskiewskiego. Pod koniec miesiąca zagon dotarł w pobliże położonego nad Wołgą grodu Starica, w którym przebywał car. Hetman litewski kazał spalić okoliczne włości, wprawiając ponoć tyrana w przerażenie.

Różnie przedstawia się ten epizod wojenny w ówczesnym piśmiennictwie. Eliasz Pielgrzymowski, naoczny świadek wydarzeń, aczkolwiek człowiek nader naiwny, w panegiryku z 1583 roku wysławiającym litewskiego magnata przekonywał:

mając Męstwo za przewodnika, a Fortunę za towarzysza, mógłbyś pojmować ową osławioną bestię i hydrę lernejską, mianowicie samego Wasiliewicza, tyrana moskiewskiego, gdyby tylko tak bardzo nie wystraszył go widok pobliskiej pożogi oraz hałas zbliżającego się twego wojska i nie uciekł rozstawionymi końmi pod osłoną srogiej z powodu ciemności i grozy nocy ze Starycy, żaląc się i drżąc ze strachu $[\ldots]^{13}$.

Dwa lata później Andrzej Rymsza, także uczestnik wyprawy Radziwiłła ${ }^{14}$, wydał w Wilnie poemat epicki Deketeros akroama, to jest Dziesięćroczna powieść wojennych spraw [...] Krysztofa Radziwiła [...], która się poczyna od roku po narodzeniu pana Chrystusowym 1572 aż do roku, który pisano 1582. Autor programowo respektował w swoim utworze zasadę weryzmu historycznego, chociaż nie stronił też od środków epickich i panegirycznych, pozwalających pasować Radziwiłła na prawdziwego Achillesa wojen z Wielkim Księstwem Moskiewskim ${ }^{15}$. W XV części żołnierskiego eposu przedstawił Rymsza akcje wojsk hetmana w pobliżu Staricy, mające pogrążyć Iwana w czarnej rozpaczy. Rymopis „przytacza” nawet jego lament (stylizowany na język ruski), w którym car daje wyraz obawom o życie bliskich i własne. Wypowiedź tę Rymsza podsumował informacją:

Po tych swoich rozmowach z swojemi bojary,

Gdzieś ujachał w szelinę sam Kniaź Wielki stary,

Bo tej nocy od niego zbiegł jego pościelnik

Daniło Murza, co był wszech tajemnic wiernik ${ }^{16}$.

${ }^{13}$ E. P i e 1 gr z y mow ski, Apostrofa panegiryczna. Oprac., przeł. B. Aw i a now icz. Warszawa 2012, s. 58-59. Nie należy tej informacji kłaść na karb laudacyjnej przesady. W dedykacji do późniejszego dzieła, w której autor wyliczył swe zasługi dla ojczyzny, za powód do chwały uznał m.in. „ono przedarcie się [...] od wojska do wojska, spod Starzyce do Pskowa z oną nowiną, że kniaź, on wielki moskiewski tyran, z dziećmi przed nami z Starzyce uciekł [...]" (E. P i e 1 g r z ymo w s ki, Poselstwo i krótkie spisanie rozprawy z Moskwa. - Poselstwo do Zygmunta Trzeciego. Wyd., oprac. R. K r z y w y. Red. nauk. D. Chemperek, J. S. Gruchała. Warszawa 2010, s. 35).

14 Zob. H. L u 1 e w i c z, Rymsza Andrzej. Hasło w: Polski słownik biograficzny. T. 33. Wrocław 1991-1992.

15 Szerzej na ten temat zob. R. K r zy w y, „A ja arma virumque zaczynam canere...” Uwagi o ksztatcie literackim poematu „, Deketeros akroama” Andrzeja Rymszy. „Wschodni Rocznik Humanistyczny" 2007, s. 24-27.

16 A. Ry m z za, Deketeros arkoama. Dziesięćroczna powieść wojennych spraw. Wyd. W. R. R z e p k a, A. S a j k o w s ki. W: Miscellanea staropolskie. T. 4. Red. nauk. R. Pollak. Wrocław 1972, s. 187. 
Ów Daniło Murza trafił 14 września do obozu królewskiego, gdzie zdał relację, jak się przedstawiała sytuacja w otoczeniu Iwana podczas śmiałych poczynań Radziwiłła. Wiadomości przekazane przez Tatara skwapliwie zanotował Jan Piotrowski, dokumentujący na bieżąco wypadki pod Pskowem. Zdrajca potwierdził, iż widok łun mocno zaniepokoił cara, który z płaczem, ,żonę, dzieci i z skarbem wodą z trzaskiem odesłał od siebie". Informował również, że władca moskiewski radził przebywającemu w mieście mediatorowi papieskiemu Antoniowi Possevinowi, by także uciekał, lecz jezuita odparł, iż się ,,wojsk polskich nie boi”. Z kolei sugestie bojarów, by wielki kniaź sam udał się do króla lub wydelegował któregoś syna, aby negocjować, Iwan miał skwitować krótko: „Jam stary, ci też jeszcze niebywali w tem”17. O planach ucieczki Piotrowski w ogóle nie wspominał. Dalej zanotował dodatkowo, że kiedy Radziwiłł przybył do obozu: „Powiadał, że 250 mil wzdłuż splądrował moskiewskiej ziemie, pod oczyma samego kniazia był" ${ }^{18}$. O przepłoszeniu władcy nie ma mowy, a wątpić należy, by hetman nie pochwalił się takim dokonaniem.

W zbliżony sposób wydarzenie przedstawił Andrzej Lubieniecki w przekazanym późniejszym wiekom w odpisach traktacie historiozoficznym Poloneutychija, abo Polskiego Królestwa szczęście, a przy tym i Wielkiego Księstwa Litewskiego, a potem tegoż szczęścia szwankowanie w roku 1612 i 1613. Autor w młodości był pokojowcem Stefana Batorego i uczestniczył w wyprawie moskiewskiej króla, dwór porzucił w roku 1582. Epizod z zagonu zapamiętał następująco:

Książęcia Radziwiłła też Krzysztofa, kasztelana natenczas trockiego, z Filonem Kmitą król posłał pod Starzycę, gdzie natenczas był sam kniaź, którzy ziemię jego pustosząc i Moskwę, gdzie się jeno pokazali, bijąc, poszli aż pod Starzycę. Za czym i sam kniaź strachu się nabrał, bo widział okiem swym ognie, które naszy palili. Przeto co rychlej wyprawił do króla Possewijona, jezuitę, którego był papież, od Moskwicina proszony, wysłał na pojednanie króla z nim. A ten, do króla przyjechawszy, uprosił u króla, żeby posłał swe posły z nim, aby się u wsi Jamy $\mathrm{z}$ moskiewskimi posłami zjechali, a tam o pokoju traktowali ${ }^{19}$.

Mimo to heroldowie Radziwiłłowskiej sławy nie pozostali obojętni na krążące pogłoski. Oficjalny historyk zmagań wojennych z lat 1579-1582, Reinhold Heidenstein, który na zlecenie Jana Zamoyskiego opracował obszerne dzieło De bello Moscovitico commentariorum libri sex (opublikowane w Krakowie roku 1584), domniemaną ucieczkę Iwana ukazał jako nie zrealizowany ostatecznie zamiar:

Musiał on [tj. Iwan Groźny] patrzeć w znacznej części własnymi oczyma na zbliżanie się naszych hufców, na popłoch chłopstwa i łuny pożarne, oświecające całą okolicę, a jak Possewin, bawiący wtenczas u niego, później opowiadał, miał on przy sobie zaledwie 700 zbrojnych. Rzecz to pewna zupełnie, że kniaź w śmiertelnej trwodze każdego bez różnicy zaciągał wtedy do wojska i o ucieczce już myślał ${ }^{20}$.

O tym, że Iwan planował zbiec, informował także Joachim Bielski w uzupełnieniach do Kroniki polskiej pióra swego ojca. Dziejopis, który najprawdopodob-

17 J. P i o tro w s k i, Dziennik wyprawy Stefana Batorego pod Psków. Wyd. A. C z u c z y ńs k i. Kraków 1894, s. 89.

${ }_{18}$ Ibidem, s. 141.

19 A. L u b i en i e c k i, Poloneutychia. Oprac. A. Li n d a [i in.]. Warszawa-Lódź 1982, s. 71.

${ }^{20}$ R. He id e n s te i n, Pamiętniki wojny moskiewskiej w 6 księgach. Przeł. J. C z u bek. Lwów 1894, s. 206. 
niej brał udział tylko w wyprawie połockiej jako urzędnik kancelarii królewskiej ${ }^{21}$ (lecz można mniemać, iż losy kolejnych ekspedycji żywo go interesowały i mógł je poznać ze źródeł w miarę pewnych), twierdził, że car faktycznie chciał uciec drogą wodną śladem swej rodziny i namawiał do tego również Possevina, lecz poseł papieski przekonywał go, by się nie bał, i z trudem zatrzymał Iwana w Staricy. Autor powołał się przy tym na ustną wiadomość jezuity, a uwiarygodniać to miało zapewne informację na temat zamiarów wielkiego kniazia: „,co zasię naszym legat Possevinus powiedał, bo z nim stał natenczas w oknie, patrząc na ognie, które widać barzo dobrze było"22.

Ucieczkę cara zdawał się natomiast sugerować Franciszek Gradowski w heksametrycznym poemacie Hodoeporicon Moschicum / Wyprawa moskiewska (dwa wydania w 1582 roku). Co prawda, bezpośrednio stwierdził jedynie, że car odesłał ze Staricy „małżonkę i dzieci, i druhów wiernych pod mrocznej nocy osłoną znacznie dalej, do zamków ojczystych [...]", lecz w nocie marginesowej zaznaczył: „Moskal ucieka ze Staricy” (,Moschus ex Starica fugit”) ${ }^{23}$, oględnie dając do zrozumienia, że i car opuścił gród. Wątpliwości nie miał za to Andrzej Trzecieski, który w utworze Triumphus Moscoviticus [...] Stephani I [...] / Triumf moskiewski [...] Stefana I [...] (1582) obwieszczał:

W tym marszu posunął się [Radziwiłł] aż w pobliże Starycy, gdzie wtedy przebywał ów car moskiewski, przez nikogo dotąd nie zwyciężony; ten zaś widząc pobliskie łuny pożarów, chociaż był chroniony przez wielką liczbę żołnierzy, w sromotnej ucieczce szukał schronienia w bezpiecznym miejscu ${ }^{24}$.

Z kolei Jan Kochanowski, który, podobnie jak Gradowski i Trzecieski, wiedzę na temat wypadków wojennych czerpał z drugiej ręki, w Jeździe do Moskwy nie chciał już skazywać swych czytelników na domysły. Z informacji o pierzchnięciu cara nie wydobył jednak możliwości pochwalnych w takim stopniu, jak to uczynił W odach batoriańskich cytowanych na początku niniejszego artykułu. W późniejszym poemacie wiadomość ta została zepchnięta na dalszy plan przez natłok dodatkowych szczegółów:

Tę [Wołgę] przepłynąwszy ludzie twoi szli w zagony

Pod Starycę, gdzie sam kniaź natenczas, strwożony,

$\mathrm{Z}$ wojskiem swoim ulegał i z miłymi syny;

A widząc gęste ognie i bliskie perzyny,

Tejże nocy żonę swą i kniazia Fiedora

Z żoną jego i z bracią z staryckiego dwora

Do Moskwy wysłał i sam barzo sobą trwożył,

I już był tylko w nogach nadzieję położył,

Zwłaszcza gdy Danił Murza od niego z Staryce

Do ciebie był ujechał, jego stróż łożnice. [w. 277-286]

${ }_{21}$ Zob. H. B a r y c z, Bielski Joachim. Hasło w: Polski słownik biograficzny. T. 2. Kraków 1936, s. 62.

${ }_{22}$ M. B i e ls k i, Kronika polska. T. 3: Księga VI wraz z kontynuacja. Wyd. K. J. Tu ro w s k i. Sanok 1856, s. 1494. Jak podaje H e i d e n s t e in (op. cit., s. 207), Possevino opuścił Staricę zaraz po ustąpieniu Radziwiłła znad Wołgi.

${ }^{23} \mathrm{~F}$. G r a d o w s k i, Hodoeporicon Moschicum. Wyprawa moskiewska. Wyd. B. C z a r s ki. Przeł. ..., A. M a s ło w s k a - N o w a k. Warszawa 2011, s. 64-65, BPS 39.

24 A. Trze ci i ski, Carmina. Wiersze tacińskie. Oprac., przeł., wstęp J. K rók o w ski. Wrocław 1958, s. 357. BPP, B 8. 
Źródła z epoki przedstawiają zatem dość niejednolity obraz wydarzenia. Niektóre w ogóle nie wspominają o rejteradzie Iwana Groźnego, inne donoszą o niezrealizowanym planie, a jeszcze inne podają bez cienia wątpliwości, że strwożony car salwował się ucieczką ${ }^{25}$. Zwłaszcza utwory o celach propagandowo-laudacyjnych (Jezda do Moskwy, Apostrofa panegiryczna, wiersz Trzecieskiego, ale także w pewnej mierze Hodoeporicon Moschicum) zdają się forsować tę wersję wydarzeń, która męstwu „Pioruna” przeciwstawia tchórzostwo wrogiego samodzierżcy ${ }^{26}$. Ten swoisty szum informacyjny to prawdopodobnie wynik mieszania się krążących pogłosek, relacji docierających od uczestników wypraw i od świadków pośrednich, przyglądających się nurtowi wydarzeń z bliska, lecz nie wystarczająco blisko, by wypowiadać sądy pewne. Niewykluczone, że w obiegu były też awizy produkowane na bieżąco z inicjatywy dowództwa przez towarzyszącą wojsku drukarnię polową ${ }^{27}$. Wszystko to potęgowało - jak się zdaje - famę sukcesu, która stała się naturalną strawą panegiryków. Można przypuszczać, iż podobny mechanizm zadziałał także w przypadku ód sławiących zwycięstwo połockie, chociaż niepotwierdzone wiadomości o pośpiesznej ewakuacji carskiej rodziny na północ szybciej przestały zaprzątać uwagę opinii publicznej, nie pozostawiwszy w źródłach - poza pieśniami Kochanowskiego - nawet śladu. Jak sądzę, realność zagrożenia, które stwarzał zagon litewski, uprawdopodobniła te „nowiny”, a zapewne i Radziwiłł był zainteresowany podtrzymywaniem ich żywotności.

Frapuje jednakże, co skłoniło Kochanowskiego, by posłać Iwana Groźnego aż nad skute lodem wody oceanu. Zastanawia też przywołana na wstępie niniejszych dociekań uwaga Niemojewskiego na temat sławy położonego na północy Biełozierska, gdzie car chciał zbiec, ,kiedy mu król Stefan dokuczał”. Kierunek rzekomej ucieczki despotycznego władcy nie jest tak zupełnie przypadkowy, gdyż ko-

${ }_{25}$ Także zresztą dzisiejsze opracowania historyczne nie udzielają jednoznacznej odpowiedzi na pytanie o zachowanie się cara w obliczu zagrożenia ze strony wojsk Radziwiłła. D. K u p i s z (Psków 1581-1582. Warszawa 2006, s. 67-68) nie wspomina o ucieczce, uznając wieści o przerażeniu wielkiego kniazia za przesadzone. R. S k r y n n i k o w (Iwan Groźny. Przeł. J. D a n c y g i e r. Warszawa 1979, s. 243) uważa, że car, ,odesławszy żonę i młodszego syna, sam zajął się przygotowaniem twierdzy do obrony". Natomiast A. A n d ru s i e w i c z (Iwan Groźny. Warszawa 2006, s. 172) pisze, iż zbiegł on, ,przerażony widmem dostania się do niewoli”.

${ }^{26}$ Nadmienić należy, że w innym utworze, obszernym poemacie pindarycznym z $1583 \mathrm{r}$. Ad Stephaneum Bathorrheum, regem Poloniae inclytum, Moscho debellato et Livonia recuperata epinicion Anno a Christo nato 1582, J. K o c h a n o w s k i zasługę wystraszenia cara przypisał Stefanowi Batoremu. Ostatni thumacz dzieła (J. K o c h a n o w s k i, Pieśń zwycięstwa nad Moskwa w wojnach o powrót Inflant rok po narodzeniu Chrystusa 1582 i inne pieśni wojenne. Przeł. W. S t a ń c z a k. Warszawa 2008, s. 171) oddał rzecz następująco:

Gdy tylko [car] dostrzegł
ognie, dym i sadze,
natychmiast zdjęty strachem
pcha toboły w łodzie
szybkie i nuż uciekać,
aż się smutny w głębi
carstwa ukryje. [...] [w. 673-679]

O utworze zob. studium Z. Gło m bi ow sk i e j O pindaryzmie „Epinicionu” Jana Kochanowskiego (w zb.: Jan Kochanowski. Interpretacje. Red. J. Błoński. Kraków 1989).

27 Zwrócił na to uwagę A. S a j k o w s k i („Odrodzenie i Reformacja w Polsce” 1982, s. 232) w recenzji książki J. P e l c a Jan Kochanowski. Szczyt renesansu w literaturze polskiej (Warszawa 1980). 
responduje $\mathrm{z}$ zawartymi $\mathrm{w}$ latopisach relacjami z wydarzeń, które rozegrały się równo wiek przed wyprawami Batorego. W roku 1480 doszło do spotkania nad Ugrą (dopływem Oki) armii Iwana III Srogiego i chana Złotej Ordy, Ahmada. Wojska stały naprzeciw siebie po obu stronach rzeki, lecz na rozkaz wodzów odsunęły się od brzegów. Następnie Tatarzy wrócili na swe stanowiska, co wprawiło wielkiego kniazia w przerażenie. Wystraszony Iwan cofnął się wraz z dworem w głąb kraju do Borowska i rozkazał ponoć swej żonie, Zoe Paleolożance - która przebywała w stolicy - by zbiegła, zabrawszy zawartość skarbca moskiewskiego, do Biełozierska; a gdyby niebezpieczeństwo okazało się groźniejsze, miała uciekać aż - jak to ujmują kronikarze - „do oceanu”. Sam także zamierzał, wedle źródeł ruskich, podążyć za małżonką. Rzecz jasna, taka wersja wypadków jest wyraźnie tendencyjna, co wynikało z niechęci przedstawiających je duchownych prawosławnych do wprowadzanych w państwie porządków bizantyjskich, które zagrażały Cerkwi. Z plątaniny faktów i pogłosek przebija w latopisach wyraźny resentyment wobec władcy połączony z oskarżeniami o tchórzostwo ${ }^{28}$.

Czy nieprawdziwe wieści o ucieczce utrwalane przez opozycjonistów kniazia mogły odbić się echem w doniesieniach o rejteradzie wnuka Iwana Srogiego? Nie da się tego wykluczyć, jeśli zważymy, że opinia publiczna w łacińskiej Europie skwapliwie wychwytywała i utrwalała informacje na temat państwa wyłaniającego się z niebytu politycznego po długiej niewoli tatarskiej. Przekazy ustne i latopisy dostarczały wiadomości nieraz bardzo niepewnych, które jednak wykazywały skłonność do petryfikacji: powtarzano je później bezkrytycznie w literaturze dotyczącej Wielkiego Księstwa Moskiewskiego ${ }^{29}$.

Także do Biełozierska przylgnęło na stałe przekonanie, że jest to miejsce schronienia carów. Obiegowe mniemanie poświadcza bestseller ostatnich dekad XVI wieku, Sarmatiae Europeae descriptio Aleksandra Gwagnina. Dzieło opublikowane po raz pierwszy w 1578 roku miało kilka wydań do końca tego stulecia, a na początku następnego zostało spolszczone przez Marcina Paszkowskiego. Opis Księstwa Białojezierskiego zawiera następujący passus:

Białe Jezioro jest kraina znamienita i szeroka, jedna z księstw ruskich, na północ nad brzegiem onego jeziora leżąca, skąd nazwisko swe ma miasto i zamek. [...] W tym jezierze jest zamek sposobnością miejsca obronny i niedobyty, w którym kniaź wielki moskiewski skarb swój zwykł chować - i tam czasu ostatniej potrzeby, gdy gwałt od nieprzyjaciela widzi, jako do jakiego azylum zwykł uciekać ${ }^{30}$.

Jeszcze Jan Chryzostom Pasek, pisząc o strachu Moskali przed siłami Rzeczypospolitej, wskazywał tę miejscowość jako miejsce ucieczki przed zagrożeniem. Przedstawiając koncentrację wojsk w 1661 roku, nadmienił: „Już Moskwa nie mieli resistendi modum, już zdesperowawszy poddać się a miłosierdzia prosić intendebant; już panowie Wolscy za Białe Jeziora swoje wyrugowali dostatki" ${ }^{31}$,

${ }^{28}$ Zob. F. Kon i e z n y, Rzekoma koalicja Litwy z Tatarami przeciwko Moskwie w 1480 (dokończenie). „Ateneum Wileńskie” 1923, nr 3/4, s. 356-364.

${ }_{29}$ Zob. R. K r zy w y, Wędrówki z Mnemozyne. Studia o topice dawnego podróżopisarstwa. Warszawa 2013, s. 47-70.

${ }^{30}$ A. G w a g n i n, Kronika W. K. Moskiewskiego i państw do niego należacych. W: Kronika Sarmacyjej europejskiej [...]. Przeł. M. P a s z k ow s ki. Kraków 1611, s. 14.

31 J. P a s e k, Pamiętniki. Wstęp, objaśnienia W. C z a p 1 i ń s ki. Wyd. 4, zmien. i uzup. Wrocław 1968, s. 177. BN I 62. „Wolskimi” określa autor ludzi mało odważnych. 
a donosząc o kolejnych zwycięstwach, informował z właściwą sobie przesadą: „bo już cały naród o tym mówił i tak uczynić miał ob metum, który Pan Bóg już był na nich dopuścił, że i z stolice za Białe Jezioro uciekali [...]"32. Nazwa miejscowości położonej na Dalekiej Północy stała się pod piórem pisarzy staropolskich metonimią moskiewskiej trwogi przed niebezpieczeństwem.

Reasumując poczynione w niniejszych rozważaniach obserwacje, stwierdzić zatem można, że wzmianki Kochanowskiego na temat ewakuacji Iwana IV na północne rubieże państwa, chociaż rozmijają się z prawdą historyczną, nie są tak zupełnie przypadkowe. Aby ukazać przerażenie cara, odwołał się poeta do wzorca propagandowego, jaki sto lat wcześniej stworzyli przeciwnicy polityczni Iwana III, którzy kazali jego małżonce, a czasem i jemu samemu, zbiec do Biełozierska albo i dalej. Fama tej wymyślonej eskapady trwała w pamięci ogółu, a miejscowość zaczęła być stale kojarzona z azylem. Pasek wysłał nawet większość mieszkańców stolicy gdzieś „za Białe Jeziora”. Toteż właśnie na Daleką Północ skierował Kochanowski cara w odach sławiących odbicie Połocka, podkreślając panikę, jaką miało u władcy moskiewskiego wywołać przekroczenie granicy Rzeczypospolitej przez armię Stefana Batorego.

Niewykluczone ponadto, że utwory te dokumentują szum informacyjny towarzyszący podówczas kampaniom wojennym. Być może, na temat ucieczki cara w trakcie pierwszej wyprawy Batorego krążyły pogłoski, które dotarły do przebywającego wtedy w Czarnolesie poety ${ }^{33}$. Doskonale taki stan rzeczy obrazuja wypowiedzi dotyczące epizodu trzeciej wyprawy: słynnego rajdu kawalerii pod wodzą Krzysztofa Radziwiłła i Filona Kmity w głąb wrogich terytoriów. Mimo pewnych, pochodzących od bezpośrednich świadków (Possevina, Daniła Murzy), informacji o niechęci Iwana do opuszczania Staricy, twierdzono, że wielki kniaź bądź na pewno zbiegł, bądź sposobił się do ucieczki. Patriotyczna racja stanu, której rzecznikiem był m.in. Jan z Czarnolasu, domagała się, by przeciwnik stchórzył ${ }^{34}$. Możliwe również, iż tę rejteradę motywowała w pewnej mierze znana Kochanowskiemu tradycja literacka (epinikion Dantyszka). Wzmianka o ucieczce wroga doskonale bowiem uzmysławiała siłę zwycięzcy, służąc celom heroizacyjnym.

\section{Ibidem, s. 186.}

33 Aczkolwiek nie jest wykluczone, że w tym czasie Kochanowski znalazł się w Wilnie, gdzie król, wracając spod Połocka, kilka dni po tryumfalnym wjeździe do miasta wystawił dokumenty istotne dla poety: przywilej zakazujący przedruków Psałterza Dawidowego oraz nominację na wojskiego sandomierskiego. Zob. M. K o r o lk o, Jana Kochanowskiego żywot i sprawy. Materiały, komentarze, przypuszczenia. Warszawa 1985, s. 219.

34 Intencja taka patronowała wyraźnie S. Tw a rdow s k i e m u (Władysław IV, król polski i szwedzki. Wyd. R. K r z y w y. Warszawa 2012. BPS 40), który, opisując wtargnięcie armii Władysława IV Wazy po odparciu wojsk moskiewskich spod Smoleńska w r. 1634, nadmienił, że Michał I Romanow szybko zorganizował obronę stolicy, ,skąd umknąć w dalsze gdzieś Tryjony [tj. na Daleką Północ - R. K.] / już beł myślił” (s. 273, V, w. 1785-1786). O takich zamiarach władcy, oczywiście, nic nie wiadomo. Odnosi się wrażenie, że w dawnym dyskursie patriotycznym wytworzyła się norma nakazująca pisarzom twierdzić w przedstawieniach polsko-rosyjskich zmagań wojennych, iż carowie ze strachu planowali ucieczkę przed potęgą królów Rzeczypospolitej. 


\section{Abstract}

ROMAN KRZYWY

(University of Warsaw)

\section{"YOU WANT TO BE TERRIBLE, BUT YOU FLEE..." ON THE COMMENTARY TO JAN KOCHANOWSKI'S MUSCOVY EPINICIONS}

The author of the study tries to explain the origin of the information given by Jan Kochanowski about Ivan the Terrible's escape to the far North of which the information is recurrently exalted in Kochanowski's pieces on Polish Republic victories in the period of the wars with the Muscovy waged by Stephen Báthory. Contrary to former commentators, the author proves that however the piece of news is incongruous with the historical truth, it is yet not accidental. First, it is an effect of a propaganda, the exemplar of which Kochanowski might have found in earlier accounts and, second, it documents the information noise that accompanied the then war campaigns. The author also notices that the information about Ivan the Terrible's alleged flight fused with the descriptions of Stephen Báthory's wars and operated also on later writers who, when describing Polish-Russian relationships, tended to claim that the feared czars planned escape from the power of the Polish Republic rulers. 